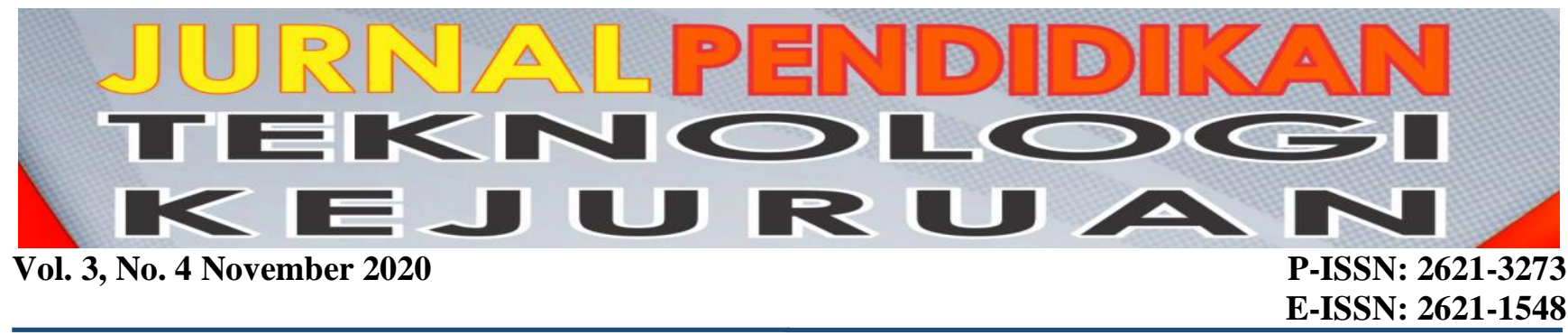

\title{
Mobile Learning Design for Basic Programming Independent Learning
}

\author{
Hafiz Elmi ${ }^{1}$, Ganefri $^{2}$ dan Dedy $\operatorname{Irfan}^{3}$ \\ ${ }^{13}$ Technology and Vocational Education Department, Faculty of Engineering, Universitas Negeri Padang \\ ${ }^{2}$ Electrical Engineering of Magister Program Study, Faculty of Engineering, Universitas Negeri Padang \\ "Corresponding author, e-mail: hafiz.elmi@gmail.com ${ }^{1}$
}

\begin{abstract}
This study discusses about design of the self-learning mobile learning basic programming based on Android. Designed mobile learning material contains an abstract discussion of programming that is not visible invisible. This material was translated by concrete and to be more easily understood by students. The method used in the design of self-learning mobile learning is SDLC (System Development Life Cycle) waterfall, and use the process of UML (unified modeling language) with the use case diagram and flowchart. The results of this study indicate that the self-learning mobile learning basic programming is easy to use for students and teachers as instruction learning.
\end{abstract}

Keywords: Mobile Learnig, Basic Programming, Android, self-learning

\section{INTRODUCTION}

Technology has developed rapidly to ease human activity. Smartphone is one of these technologies. As cited from kemenprin.go.id that there are three penetrations in Indonesia or cellular phone growth is reached $62 \%$ per year. In line with that teknoflas.com said that there is prediction of smart phone analysis, particularly in Indonesia in which it will reach 12 to 15 million units. Next, this sale will be divided into two parts, namely, OS Android user reaches 50 to $60 \%$. Meanwhile, the user of Blackberry is $30 \%$.

However, the vast developed technology is not equal to the use of smart phone in teaching and learning process. One of the uses of smart phone technology in teaching and learning process is the use of mobile learning as a tool in independent learning. Learning process by using mobile learning has a very flexible characteristics since it can be use anytime, anywhere, also it has probability which is adequately high so that student can access learning material and information anytime and anywhere. The used learning media comes up in the form of mobile learning.

In the curriculum, each of the skill competences consist of basic programming learning subject for student of grade X. Basic programming is one of the compulsory learning subjects at the basic of Computer Technique Skill and Informatics program.
The observation conducted revealed that there are numbers of Basic Competences (KD) which the students found them hard to understand. This can be seen from the average score of Daily Test (UH) of 1st Term and Daily Test (UH) of 2nd Term of web programming learning subject of Grade X, Public Vocational High School (SMK) 6 Padang.

The development of mobile learning program conducted are reviewer assessment and peer reviewer of android based mobile learning with a very good quality $(87.78 \%)$ and students' respond revealed that android based mobile learning has a good quality (79.71\%) (Sambodo, 2014). Thus, these proved that android based mobile learning can be used in the teaching and learning processes and it is suitable to apply. The other related research also revealed that the use of mobile learning affected completeness score in which the number of students who pass the pretest is $40 \%$, meanwhile posttest is $80 \%$ (Nurjayanti, 2015)

The development research conducted by the previous researcher revealed that mobile learning is effective to be used as learning supporting device. Therefore, the researchers are encouraged to conduct the development research on Android based mobile learning for Basic programming learning subject with its basic competence is to implement programming language.

Basic competence is to implement programming language which consists of materials about 
programming

language

implementation, tools/framework introduction, installation, programming language structure, output and input standard of programming language, compilation and execution, and error correction material. The characteristics of this learning subject is that students need some time to understand and need further practice which require the role of supporting media which students can found it useful for them to learn the learning subject. Very Strong understanding of this learning material is required so that the students can repeat to learn this material anytime and anywhere. The development of learning supporting media in the form of mobile learning is expected to be able to facilitate student and teacher needs every time in learning this material.

\section{LIBRARY RESEARCH}

The word media originated from the word medius which is Latin language. Medius means middle, mediator of the deliverer to the receiver (Arsyad, 2011). Generally, the word media can be translated as human, material or event to enrich the knowledge of the student cognitively, affectively and skillfully (Gerlach et al, 1971).

AECT (Association of Education and Communication Technology, 1997) stated that "medium is the mediator to deliver information from the source to the receiver. Communication media is a kind of printing materials, television, radio, photo, film, audio recording which brings communication messages. Meanwhile, teaching media is a media employed to bring message or information in an instructional way or containing teaching aims".

Visual stimulus is better to help to remember, introduce, as a reminder, and to connect word and concept. However, when learning is involving sequential memory, then the result will be better by using verbal stimulus (Arsyad, 2013)

In teaching and learning process, teacher needs a learning media to deliver information to students and interaction between student and the environment. In addition, media is also to display the advantage and the disadvantage of a teaching and learning process.

Interactive multimedia is a media which its control system can be used by the user, for example: interactive learning and game. Meanwhile, learning multimedia is a multimedia application which is used in the learning process to allow message delivery, selecting stimulus, affection, attention, and students' willing, so that teaching and learning process can take place (Zaus, et al, 2019).

Mobile learning in the future time can be a lifetime learning instrument (Holzinger et al, 2005). There are three functions of mobile learning, namely, classroom instruction which is as an optional, complement, or substitution supplements (Siahaan, 2011)

Android is a comprehensive open source platform which specifically designed for mobile devices and developed by Open Handset Alliance leads by Google (Gargenta, 2011). As for the developer, Android provides all tools and frameworks to develop mobile application in ease, fast, open, and free. SDK (Software Development Kit) Android is a basic element to develop Android".

The main characteristics of independent learning according to Moore are the availability of opportunity given to the students to determine their goal, source, and evaluation of their learning. Hence, independent learning program can be classified based on the width of the freedom given to the students to participate in determining their learning program (Rusman, et al, 2013).

\section{METHOD}

This research resulted in a learning media. System Development Life Cycle (SDLC) waterfall method is employed as the research method. Systematic approach of SDLC method is implemented in a sequence from the beginning to the last stage which involves system integrity analysis, analysis, coding design, testing, and maintenance

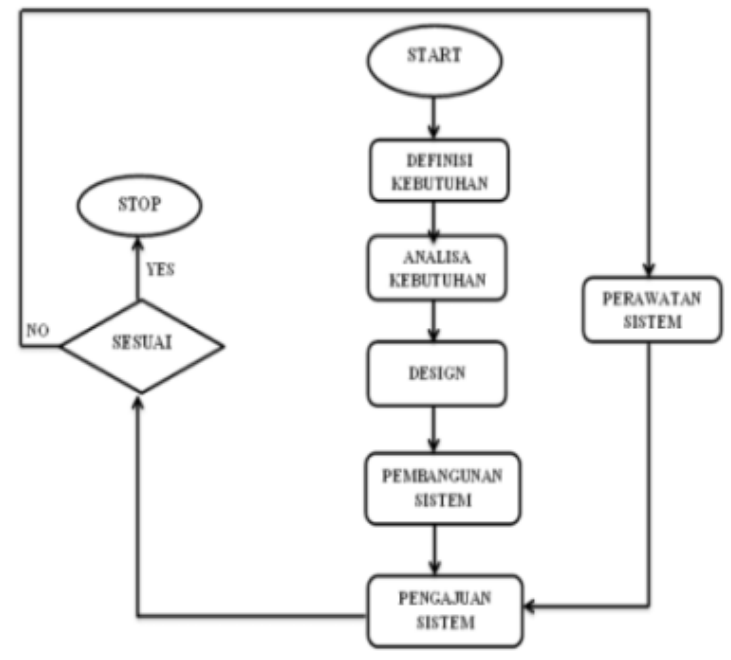

Figure1. SDLC Waterfall Mobile Learning Method

The ease of use test of mobile learning for basic programming independent learning by using questionnaire filled by teacher and student. Prior to that, this media needs to be validated first. Data obtained from the result of score tabulation result need to be percentaged by using formulation.

$$
\text { practicality value }=\frac{\text { Total score of each answer }}{\text { Total score of ideal item }} 100 \%
$$

The result of score percentage of media practicality by teacher and student which is categorized as follow: 
Table 1. Practicality Category

\begin{tabular}{|l|l|l|}
\hline No & Achievement Level & Category \\
\hline 1 & $81-100$ & Very Practical \\
\hline 2 & $61-80$ & Practical \\
\hline 3 & $41-60$ & Fairly Practical \\
\hline 4 & $21-40$ & Less Practical \\
\hline 5 & $0-20$ & Impractical \\
\hline
\end{tabular}

Research flow/flowchart can be drawn as follow:

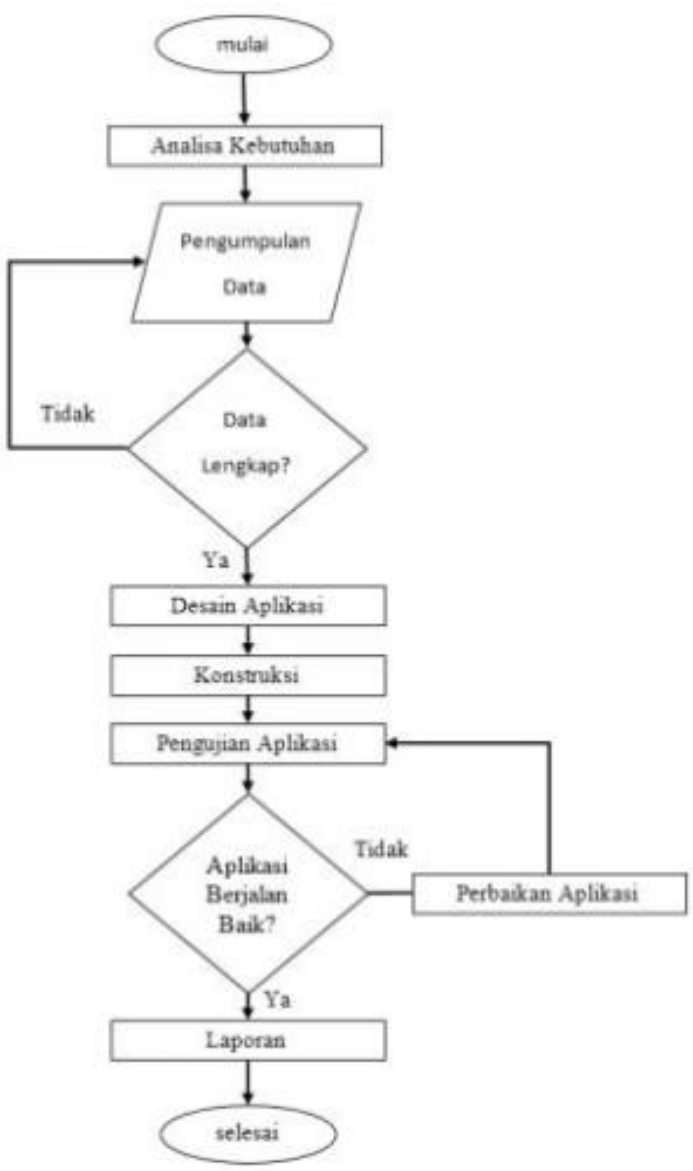

Figure 2. Flowchart of mobile learning design

\section{RESULT AND AND DISCUSSION}

This learning media design is started by first conducting system needs analysis, then continued with designing application interface design, after that interpretation in the making of system (coding) of learning media, to finally test the media to student and teacher who will use mobile learning for basic programming independent learning.

Below is the result of mobile learning for basic programming independent learning.

\section{Main Menu Page}

The display of main menu page may contain submenu page/page based on the function of the button.

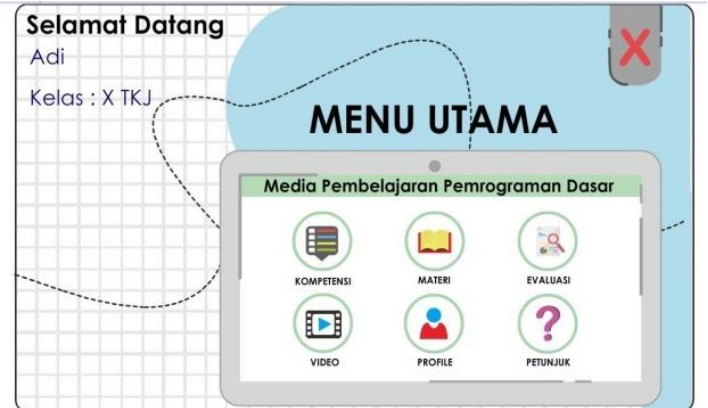

Figure 3. Main menu page

The main menu page consists of five menu buttons and navigation. Each of menu button works based on its own usage..

a. Competence Menu is to display basic competence in the mobile learning.

b. Material menu is to drive user to the material page from the mobile learning for basic programming independent learning.

c. Evaluation menu is to display learning exercise page.

d. Video menu is to display many learning videos.

e. Profile menu is to display developer identity page.

f. Directory menu is to help the user in operating mobile learning.

g. Exit button is to close the application.

Evaluation menu page contains exercise question to allow students to evaluate their ability on basic programming material and to be able to out username as login identity of mobile learning independent learning basic programming.

\section{Material Page}

Material page is a page contains many choice of learning activities which is adjusted with the basic competence. There are five submenus of learning activities that will include learning material information.

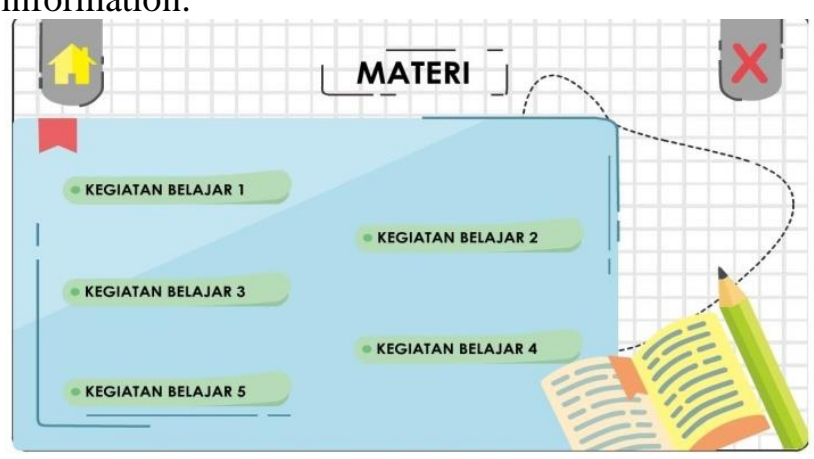

Figure 4. Material menu page 


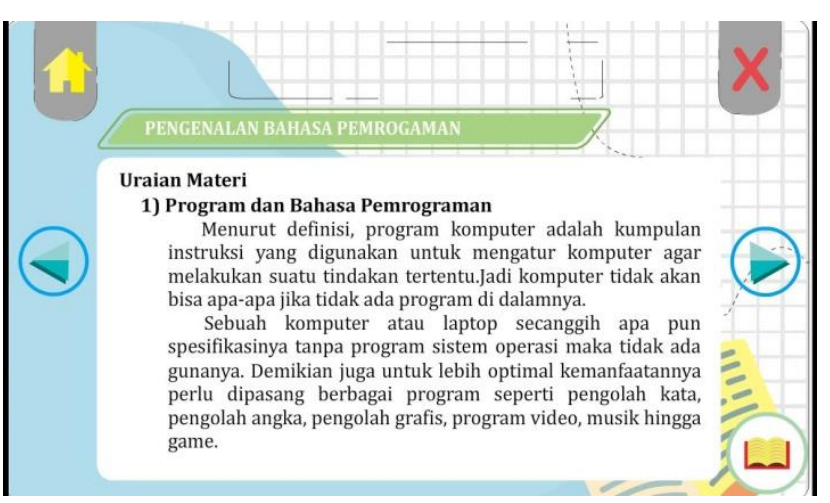

Figure 5. Material page

3. Video learning page

Learning video page contains some submenu buttons including video display. Each button will display video based on the name of the displayed button which has been adjusted with the material of basic programming basic competence..

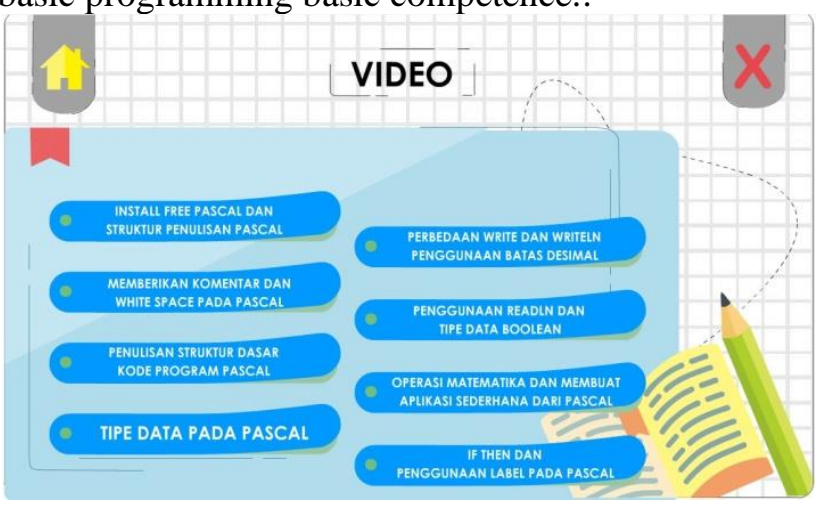

Figure 6. Video learning page

\section{Competence page}

Competence page is a page contains core competence and basic competence of mobile learning for basic programming independent learning.

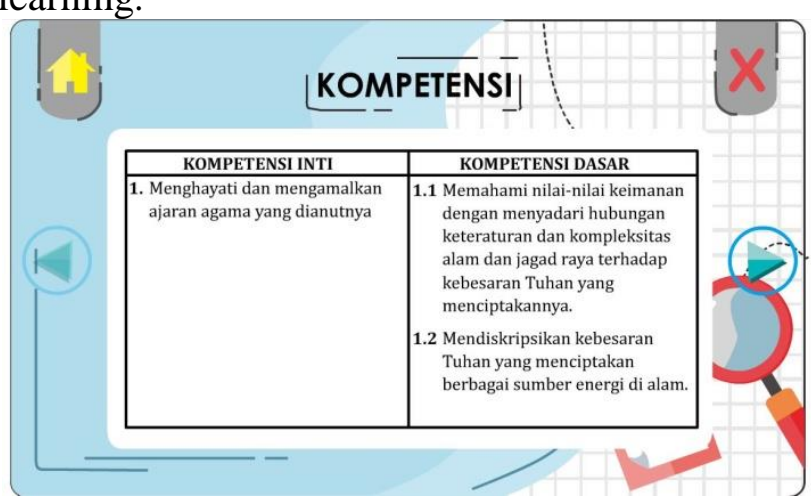

Figure 7. Competence page

\section{Evaluation Page}

Evaluation page will display many exercises related with the learning material, so that students can evaluate their understanding ability about basic programming. The evaluation can be in the form objective question type consists of five multiple 202 choices.

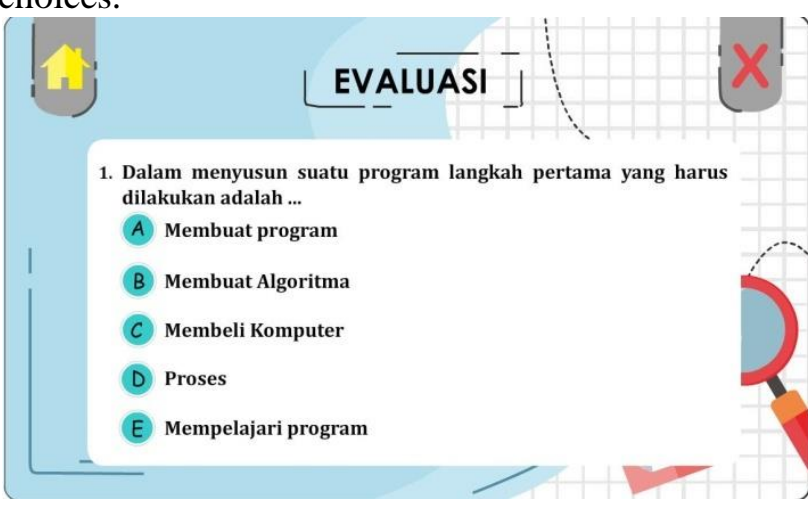

Figure 8. Evaluation page

After the media has been developed, the next step is to test the ease of usage of this mobile learning toward teacher and student, below is the result of ease of usage test/practicality test of mobile learning for basic programming independent learning

Table 2. Respond data of teacher/practitioner

\begin{tabular}{|l|l|l|}
\hline Aspect & $1^{\text {st }}$ Practitioner & $2^{\text {nd }}$ Practitioner \\
\hline Technical & 88 & 92 \\
\hline Content & 88 & 92 \\
\hline Design & 84 & 88 \\
\hline
\end{tabular}

Table 2 revealed that total percentage of 1 st practitioner's respond toward technical and content aspects is $88 \%$, meanwhile 2nd practitioner's respond toward technical and content aspects is $92 \%$ and the design aspect is $88 \%$; hence all aspects of mobile learning for basic programming independent learning can be categorized as very practical.

Table 3. Students' respond data

\begin{tabular}{|l|l|l|}
\hline Aspect & $\begin{array}{l}\text { Assessment } \\
\text { Percentage } \\
(\%)\end{array}$ & Category \\
\hline Practicality & 83,52 & Very Practical \\
\hline Motivation & 83,31 & Very Practical \\
\hline Attractiveness & 82,67 & Very Practical \\
\hline Advantage & 82,49 & Very Practical \\
\hline
\end{tabular}

Table 3 revealed that total percentage of students' respond toward practicality aspect is $83.52 \%$, motivation aspect is $83.31 \%$, attractiveness aspect is $82.67 \%$, and the advantage aspect is $82.49 \%$; hence all aspects of mobile learning for basic programming independent learning can be categorized as very practical.

Based on table 2 and table 3, it can be concluded that mobile learning for basic programming independent learning is practical or easy to use by teacher and student. 


\section{CONClusion}

Based on mobile learning design for independent learning, it can be concluded that mobile learning has been developed properly ranging from need analysis process, design configuration, the making and the assessment toward media development. Both teacher and students' respond revealed that mobile learning is practical to be used. The practicality test of this mobile learning showed that this device is appropriate to be used as independent learning media which can be seen from its practicality to be used by teacher and student in the learning activity. Teacher can use this research as a description, reference addition, and as an alternative to encourage the use of innovative learning media in order to enrich students' knowledge.

\section{BIBLIOGRPAHY}

Arsyad. 2013. Media Pembelajaran. Jakarta: PT. Raja Grafindo Persada

A. I. Nurjayanti, 2015. "Pengembangan Multimedia Pembelajaran Matematika Berbasis Android Untuk Siswa Kelas 3 Sekolah Dasar," Universitas Negeri Yogyakarta.

M. Gargenta, 2011. Learning Android.

M. Holzinger, A., Nischelwitzer, A., \& Meisenberger, 2005. "Mobile phones as a challenge for m-learning: examples for mobile interactive learning objects (MILOs)," in In Third IEEE International Conference on Pervasive Computing and Communications Workshops, pp. 307-311.

M. Siahaan, 2011. "Pengembangan Mobile Learning berbasis Audio Sebagai Alternatif Model Pembelajaran Bidang Studi Bahasa Indonesia di SMK N 8 Semarang," Universitas Negeri Semarang.

R. A. Sambodo, 2014. "Pengembangan Media Pembelajaran Mobile Learning (m-learning) Berbasis Android untuk Siswa Kelas XI SMA/MA," Universitas Islam Negeri Sunan Kalijaga.

Rusman et al., 1971. Pembelajaran Berbasis Teknologi Informasi dan Komunikasi. Jakarta: PT. Raja Grafindo Persada, 2013.V. S. Gerlach, D. P. Ely, and R. Melnick, Teaching and media: A systematic approach. NJ: Prentice-Hall.

Zaus, Mahesi Agni, Krismadinata, Nurhasan Syah, Nizwardi Jalinus, Rizky Ema Wulansari, and Syaiful Islami. 2019. "Development Instructional Media on Static and Dynamic Electrical Based on Android as Student Center Learning Media." International Journal of Scientific and Technology Research 8(11):3589-91.

\section{AUTHOR BIOGRAPHY}

HAFIZ ELMI - born in Padang, November 28, 1991. Obtained a Bachelor of Education (SPd) from Universitas Negeri Padang in 2016. Then continued his master's degree at Universitas Negeri Padang in 2017. Currently the author is a master student at Padang State University and as a teacher at SMA YAPI Padang. Authors can be contacted at the email address: hafiz.elmi@gmail.com

GANEFRI, P.HD - Professor of Technological Sciences / Electrical technology and engineering Prof. Ganefri, M.Pd, $\mathrm{Ph}$, D Born in Payakumbuh, West Sumatra Province, December 17, 1963. He was appointed Rector of UNP on July 20, 2016. Previously Prof. Ganefri serves as Chairman of Kopertis Region X and Dean of the Faculty of Engineering (FT) Padang State University. Graduated with a Bachelor of Electrical Education from IKIP Padang (1988), he continued his Postgraduate Study of Technical and Vocational Education at IKIP Yogyakarta (1996) and earned a Doctorate in Vocational Technical Education at UKM Malaysia (2011).

DEDY IRFAN - Born in Padang, April 8, 1976, currently as a lecturer in the Department of Electronics Engineering, FT UNP and a functional Lector position. S1 majoring in electronic engineering, FT UNP (2000), S2 at UPI YPTK Padang (2009) and S3 at UNP (2014). 